\title{
The Research Foundation to Tree Pruning: A Review of the Literature
}

\author{
James R. Clark and Nelda Matheny
}

\begin{abstract}
Two hundred one research publications including 152 journal articles were compiled. Forty-four journals were represented with the Journal of Arboriculture, Arboricultural \& Urban Forestry, and Arboricultural Journal as the most frequently cited. Compartmentalization, wounding, wound response, decay development, and wound treatment were the most frequently noted topic areas. The bibliography was organized in Zotero, an application using the Firefox web browser. Keywords were identified for each publication. Where either the article or its abstract was available, an annotation was created. This paper describes the major topic areas identified in the review and discusses the future directions for pruning research.

Key Words: Tree Pruning; Literature Review.
\end{abstract}

Pruning is at the heart of arboriculture, one of the most important services arborists provide. To paraphrase Alex Shigo (1989), pruning can be one of the best things an arborist can do for a tree and one of the worse things an arborist can do to a tree. Pruning impacts both tree health and structure. It is practiced worldwide.

In 2007, the International Society of Arboriculture (ISA) contracted HortScience, Inc. to prepare a literature review on the topic of pruning. The focus of the review was the research literature. The emphasis was on arboriculture but the review could reference forestry and pomology literature as appropriate.

\section{MATERIALS AND METHODS}

In developing the review, the authors focused on peer-reviewed sources, particularly scientific journals. The process was initiated by compiling references from standard industry references such as Gilman's Illustrated Guide to Pruning (2nd edition, 2002), and Arboriculture (Harris et al. 2004). The authors also relied on O'Hara's review of the forestry literature dealing with pruning and wounding (2007). The online archive of the Journal of Arboriculture and Arboriculture \& Urban Forestry were searched for titles containing the word "pruning." There were 42 citations, some of which appeared prior to 1990-a period when articles in the Journal of Arboriculture were not necessarily research based. Major industry standards used in the U.S. (ANSI 2008) and Europe (British Standards Institute 1989; ZTV-Baumpflege 2001; European Arboricultural Council 2008) were then reviewed as well as their supporting publications (Gilman and Lilly 2002; Kempter 2004; Lonsdale 2008).

ISA specifically requested an effort to access literature from non-English sources. Literature from outside North America was queried in several ways. First, two English-language journals published in Europe, the Arboricultural Journal (Arboricultural Association, UK) and Urban Forestry and Urban
Greening (Springer) were reviewed. This approach yielded good results with Schwarze et al. (2007) and Dujeseifken (2002) as examples. Second, links to non-English publications were searched. Finally, a draft of the literature review was sent to scientists in Germany, Denmark, Italy, and France for comment. Additional references were then incorporated.

There were limitations to this approach. First, journals published in languages other than English were generally inaccessible. Second, papers where pruning was not a keyword may have been missed. Third, journals with limited exposure and nonpublished dissertations were likely omitted. Fourth, no commercial or university databases were used.

Zotero (www.zotero.org) was selected as the bibliographic management program. The program links to Firefox's Mozilla web browser. For each citation, keywords (called "tags" in Zotero's lexicon) were identified. In addition, an annotation ("note" in Zotero) was prepared (Table 1). The breadth of both keywords and annotation was limited by access to the complete paper. Journal of Arboriculture and Arboriculture \& Urban Forestry were unique in that the online archive was completely accessible to members of the International Society of Arboriculture. Older issues can be accessed without membership. Most journals, however, were not fully accessible. In almost all cases, abstracts were used. Approximately $75 \%$ of the citations had access to the full article. In the remaining $25 \%$, annotations were either very limited or not entered.

\section{DESCRIPTION OF THE CITATIONS}

Two hundred one citations were assembled. Among this group were 20 books and 10 book sections. These had broad focus and were included to identify general resources. For the professional arborist, Gilman (2002) is likely to be the best reference as it covers all aspects of the topic from young trees to mature specimens, in a variety of settings. The book is also well-illustrated. 
Table 1. Examples of annotations included in the literature review.

Gilman, E.F., and G. Knox. 2005. Pruning type affects decay and structure of crapemyrtle. Journal of Arboriculture 31:38-47.

Established Lagerstroemia $\times$ Natchez trees were topped, pollarded or unpruned for four years. Topping resulted in more dead stubs and discolored wood than pollarding which had limited decay development. Recommended developing pollards rather than routine topping. Nice photos. Florida US.

Neilsen, W., and E. Pinkard. 2003. Effects of green pruning on growth Pinus radiata. Canadian Journal of Forest Research. 33:2067-2073.

Crowns of 6- to 8-year-old, plantation Monterey pine were raised. Raising to $45 \%$ of tree height had no effect on growth which was reduced with greater crown removal. Suggests maintaining a live crown ratio of 55\%. Tasmania Australia.

Schwarze, F., J. Gruner, M. Schubert, and S. Fink. 2007. Defence reactions and fungal colonization in Fraxinus excelsior and Tilia platyphyllos after stem wounding. Arboricultural Journal 30:61-82.

Describes the anatomy of the barrier zone (= CODIT wall 4), suggesting that differences in this zone account in part for species differences in decay resistance. Strong within species variation in discoloration associated with both increment borer holes and chain saw cuts to the stem. Also isolated fungi from around the wounds. Excellent photos. Good discussion of fungal development and tree response. Freiburg Germany.

Forest tree pruning was represented by Mayer Wegelin's papers (1936; 1952), the silvicultural textbook of Smith et al. (1996), and a Hanley et al. (1995) volume on pruning of conifers. Also referenced were resources written in German (Hoster 1993; Dujesiefken 1995; Pfisterer 1999; Stobbe et al. 2002a; Stobbe et al. 2002b), and French (Drenou 1999; Austad and Hauge 2007). Palms were referenced through Broschat and Meerow (2000). For the most part, books were included as general references to the topic of pruning but lacked extensive references to the scientific literature.

Journal articles comprised 152 of the 201 citations. Forty-four journals were referenced, published in 12 countries (Table 2). Journal of Arboriculture (51), Arboriculture \& Urban Forestry (12), and Arboricultural Journal (9) were the most frequently referenced. Journals cited originated in Europe (25), North America (17), and the Asia-Pacific region (2).

More than half of the journals (24) were focused on forestry and forest science. Another 10, such as American Journal of Botany, were oriented to the traditional plant sciences. Three journals were horticultural in focus; another five were oriented to arboricultural and urban forestry. Two journals, Trees-Structure and Function and Tree Physiology, crossed lines among forestry, arboriculture, and horticulture.

Citations arose primarily from English language journals (113 of 201). Some journals, notably Arboriculture \& Urban Forestry, Arboricultural Journal, Canadian Journal of Botany, Canadian Journal of Forest Research, and Journal of Arboriculture may provide abstracts in languages other than English. Also included were citations in French, German, and Italian.

A small fraction of the citations had not undergone the normal peer-review process. Four citations were reports of the USDA Forest Service, all authored by Shigo (Shigo and Larson 1969; Shigo and Marx 1977; Shigo at al. 1979; Butin and Shigo 1981). Such reports are normally reviewed by other scientists within the agency. Articles in Arborist News, such as
Fraedrich and Smiley (1996) and Guggenmoos (2007), receive technical review. The nature of the review for books, industry standards, extension publications, conference proceedings, and book sections was unknown. The main reason for including material that had not been peer-reviewed was to highlight a specific pruning topic. This will be discussed in the following section.

A list of all authors was compiled. The most frequently cited authors were Alex Shigo of the United States and Dirk Dujesiefsken of Germany. Both were noted 13 times. Authors cited with four or more references included Ed Gilman, Jason Grabosky, Brian Kane, Dan Neely, and Tom Smiley of the United States; Karen Barry and Elizabeth Pinkard of Australia; W. Liese, D. Eckstein, Francis Schwarze, and Horst Stobbe, of Germany; and Francesco Ferrini of Italy.

\section{MAJOR TOPICS IN PRUNING RESEARCH}

Research topics were identified by the frequency with which keywords were applied. The following discussion highlights a portion of the literature included in the bibliography.

The dominant theme of the literature review was wounding, the tree's response and possible treatments to affect that response. Wounding and the tree response, to it were together noted as keywords in 30 of the 201 citations. They were often linked to compartmentalization (24 citations), decay (25), and wound dressing (10). O'Hara (2007) provided a review of the literature on this topic, emphasizing wound response and the goal of producing clear wood in timber.

Modern research activity in this area might begin with Shigo and Larson's (1969) photographic summary of the patterns of discoloration and decay in hardwoods of the northeastern U.S. This report focused on the relationship of external appearance to wood quality. It was observational in nature, rather than founded in experimentation. One finding was that covering pruning wounds with "dressings" neither improved closure nor reduced the presence of decay.

In 1977, Shigo and Marx released their seminal report Compartmentalization of decay in trees, which introduced the CODIT concept. Shigo et al. (1979) then reported on the relationship of flush cuts to the development of internal decay and other defects in black walnut (Juglans nigra). The authors noted, "When pruning is done late in the life of a tree, care must be taken not to remove the branch collars that form about the bases of dead and dying branches." Also in 1979, Shortle expanded on the compartmentalization model with very well-illustrated paper. He posed the "heartrot" concept, describing how external wounds allow decay fungi to enter and become established in the tree. Development of the CODIT model culminated with two publications: How tree branches are attached to trunks (Shigo 1985) and Compartmentalization: A conceptual framework for understanding how trees grow and defend themselves (Shigo 1984). As noted previously, the vast bulk of this work was observational in nature.

Shigo was neither the only scientist interested in tree response to wounding nor the first to examine it. For example, foresters have long had an interest in tree response to pruning and wounding (McQuilkin 1950; Herring et al. 1958; O'Hara 2007). Von Aufsess (1975) noted the formation of a protective zone at the base of branches. Neely $(1970 ; 1979)$ observed that production of callus (i.e., woundwood) at the margins of pruning wounds was related to tree vigor, as measured by growth.

Research on the topic of tree wound response and its management continued through the following decades. Experiments 
Table 2. Journals referenced in the pruning bibliography.

\begin{tabular}{|c|c|c|}
\hline Journal & Origin & No. of Citations \\
\hline Acer & Italy & 7 \\
\hline Agroforestry Systems & Netherlands & 1 \\
\hline Allgemeine Forstzeitschrift & Germany & 1 \\
\hline American Journal of Botany & United States & 1 \\
\hline Annals of Applied Biology & United Kingdom & 3 \\
\hline Annals of Botany & United Kingdom & 1 \\
\hline Annual Review of Phytopathology & United States & 1 \\
\hline Arboricultural Journal & United Kingdom & 9 \\
\hline Arboriculture \& Urban Forestry & United States & 12 \\
\hline Biological Conservation & United Kingdom & 1 \\
\hline Biotechnology Agronomy Society \& Environment & Belgium & 1 \\
\hline Canadian Journal of Botany & Canada & 1 \\
\hline Canadian Journal of Forest Research & Canada & 7 \\
\hline European Journal of Forest Pathology & Netherlands & 1 \\
\hline European Journal of Forest Research & Germany & 1 \\
\hline Forest Ecology and Management & United States & 5 \\
\hline Forest Pathology & United States & 1 \\
\hline Forest Science & United States & 1 \\
\hline Forestry & United Kingdom & 1 \\
\hline Forst und Holz & Germany & 1 \\
\hline Forstwissenschaftliches Centralblatt & Germany & 3 \\
\hline Holz als Roh- und Werkstoff & Germany & 1 \\
\hline Holzforschung & Germany & 2 \\
\hline HortScience & United States & 3 \\
\hline International Association Wood Anatomy Bulletin & United States & 1 \\
\hline Journal of American Society Horticultural Science & United States & 2 \\
\hline Journal Applied Ecology & United Kingdom & 1 \\
\hline Journal of Arboriculture & United States & 51 \\
\hline Journal of Forestry & United States & 5 \\
\hline Journal of Wood Science & United States & 1 \\
\hline Neue Landschaft & Germany & 1 \\
\hline New Forests & United Kingdom & 1 \\
\hline New Phytologist & United Kingdom & 1 \\
\hline New Zealand Tree Grower & New Zealand & 1 \\
\hline Phytopathology & United States & 1 \\
\hline Proc. American Society of Horticultural Science & United States & 1 \\
\hline Schweizerische Zeitschrift fur Forstwese & Germany & 1 \\
\hline Sherwood & Italy & 4 \\
\hline Silva Fennica & Finland & 2 \\
\hline Tasforests & Australia & 1 \\
\hline Tree Physiology & United Kingdom & 1 \\
\hline Trees - Structure \& Function & Germany & 4 \\
\hline Urban Forestry \& Urban Greening & Denmark & 5 \\
\hline Western Journal Applied Forestry & United States & 1 \\
\hline
\end{tabular}

focusing on application of wound dressings generally found materials to be ineffective. There has been excellent work studying the development of reaction and barrier zones in response to wounding of all types. Dujesiefken et al. (1999), Barry et al. (2000), Pearce (2000), Schwarze (2001), and Schwarze et al. (2007) provide detailed, very well-illustrated analyses.

The question of whether to employ flush or natural target (i.e., collar) cuts has generally sided with the latter (Deflorio et al. 2007). O'Hara (2007) suggested that one type or style of cut may not meet all management needs. Researchers tend to agree that smaller pruning wounds are preferable to larger ones, and pruning is most appropriate on young trees.

Research in the area of wound response has also involved examinations of branch structure and strength. Eisner et al. (2002b) characterized the relative size of branch to stem as aspect ratio and used this measure to assess response to pruning. Removal of branches with aspect ratios greater than 0.39 in red maple (Acer rubrum) and 0.59 in southern live oak (Quercus virginiana) resulted in greater discoloration in the parent. Branches with a more vertical orientation were more likely to have pith continuous with the stem. Removal of limbs with this pith connection resulted in more discoloration in the parent stem. Gilman and Grabosky (2006) observed that as aspect ratio increased, the amount of discoloration and decay also increased. Another key finding was the observation that pruning can slow down the growth of a codominant stem to the extent that a branch protection zone forms. Another facet of branch structure research has been the documentation that as aspect ratio increases, strength decreases (Gilman 2003; Kane 2007; Kane and Farrell 2008).

At the current time, the Hamburg Tree Pruning System (Dujesiefken and Stobbe 2002; Dujesiefken et al. 2005a) may best represent the evolution of research into wound response. It is based on observations of 750 wounds on 115 mature street and park trees. The system is based on the natural target pruning approach and has been integrated into German standards.

Another important topic encountered in the review was pruning around overhead utility lines (16 citations). The topic first appeared in the Journal of Arboriculture in conference papers during the 1980s (Holewinski 1983; Johnstone 1983). Both raised ideas of using what has become known as either natural or directional pruning rather than traditional roundover trimming. Goodfellow et al. (1987) demonstrated that directional pruning resulted in less regrowth than roundover. Johnstone (1988) followed with a description of how directional pruning could be successfully integrated into a utility's vegetation management program. Directional pruning certainly came of age with the publication of Pruning trees near electrical utility lines (1990), also known as Shigo's "yellow book." Although it was not a research-based publication, the yellow book became a key element of utility practice. It has largely been superseded by Kempter's (2004) summary of best management practices.

In recent years, research in the utility side of arboriculture has focused on three areas: 1) service reliability (Galvin 2005; Guggenmoos 2007), 2) impacts of pruning on tree structure and stability (Browning and Wiant 1997; Dahle 2006a; Dahle 2006b), and 3) the response of property owners to changes in practice (Close 2001; Kuhns and Reiter 2007).

Outside of the U.S., there has been essentially no research in the utility arboriculture area, at least that which has been published in English language journals. One exception was Millet and Bouchard's (2003) application of the French architectural analysis methods to the utility setting. They suggested species architectural patterns should be considered in making pruning decisions.

Municipal arborists have benefited from research dealing with pruning of street trees (10 citations). In 1981, Miller and Sylvester addressed the question: What is the appropriate length of the pruning cycle for municipal trees? Using Milwaukee, WI, as a test case, they concluded four to five years was the appropriate pruning cycle. They observed that tree condition declined as the length of the pruning cycle increased. Toussaint et al. (2002) provided a somewhat similar assessment for European linden (Tilia $\times$ europaea) street trees in France. They 
contrasted the costs of routine pruning to those associated with topping, finding the former both less expensive and less damaging in the long-term. Campanella et al. (2009) followed this with an assessment of the long-term costs of roundover, restoration, and thinning of European linden street trees in Belgium.

Nowak (1990) evaluated the results of street tree inventories from 11 tree species in the U.S. He observed strong speciesspecific results in pruning requirements, suggesting that pruning cycle may be species-specific. American elm (Ulmus americana) and boxelder (Acer negundo) had the most urgent need for pruning, with London plane (Platanus $\times$ acerifolia) and honeylocust (Gleditsia triacanthos f. inermis) the least urgent.

Ehsen (1987) described street tree pruning in Germany with a focus on how pruning needs change over the tree's life-span, moving from a focus on training in young trees to maintenance (e.g., cleaning and raising) on mature trees to reduction in overmature trees. Balder et al. (1997) summarized street tree selection and management in Germany, using Berlin as an example. Mascelli et al. (2008) used street trees in Prato, Italy, as a case study of pruning and management.

The research foundation for the range of types or styles of pruning varies widely. In some areas, research is only now catching up with long-time practice. In others, research provided clear direction to practice. Where to make cuts and the need to use wound dressings is but one example. The methods for, and value of, pruning young trees to develop good structure has been welldocumented whether pruning involves retaining low branches (Leiser et al. 1972), or selective bud removal (Oleksak et al. 1997).

In contrast, other pruning practices have less well-developed foundation. There is no research to suggest crown thinning improves either tree health or structural stability. And, while it has been common practice for many years, reduction pruning to a branch at least one-third the diameter of the stem lacked a scientific basis. It was not until Grabosky and Gilman (2007) evaluated reduction cuts on two mature oak species that a tentative basis could be established.

The architectural style of pruning is common in France (Stefulesco 1995; Drenou 1999; Drenou 2000). In many ways, research has followed practice, as this pruning technique is quite old. Timing and techniques of architectural pruning have been elucidated by the research of scientists such as Bory et al. (1996) and Clair-Maczulajtys et al. (1999) who have focused on carbohydrate storage patterns in trees. Pollards are also a common feature of the European landscape. Both Austad and Hauge (2007) and Ferrini (2006c) discuss their physiology and management.

Much of the work with crown-raising has occurred in forestry, where the objective is to have the lower trunk free of branches. From Slabaugh (1957) to Neilsen and Pinkard (2003), research has documented that removal of up to $50 \%$ of the live crown of young trees by lifting does not adversely impact growth. In summarizing the results from 8 field studies with Douglas-fir (Pseudotsuga menziesii), O'Hara (1991) suggested 33\% crown removal as the limit.

Pruning is considered one of the important tools in the practice of plant health care. Svihra (1994) summarized the literature regarding eradicative pruning (i.e., the removal of infested and infected branches). Pruning has been used to manage disease problems such as Dutch elm disease (Gregory and Allison 1979) and oak wilt (Appel 1994; Camilli et al. 2007). It is also important in the management of bronze birch borer (Ball 1992) and bark beetles (Barger and Cannon 1987). One of the key results of such work is the knowledge that many insects are attracted to fresh pruning wounds. For this reason, pruning should take place when insects are not active.

Arborists have long believed that proper pruning reduced the likelihood of damage during storms. Duryea et al. (1996) documented the effects of Hurricane Andrew in Florida, supported this observation for some species. Luley et al. (2002) documented branch failures in sweetgum (Liquidambar styraciflua) trees in Rochester, NY, over an eight-year period. Pruning did not reduce the number of failures (most of which occurred while the tree was in leaf), but did result in fewer service requests. Kane (2008) examined the pattern of tree failure following a severe windstorm in Massachusetts finding that pre-storm pruning "had little effect on (tree) failure."

Pruning has been used as a tool in evaluating tree response to wind, particularly related to the affect on trunk movement. Smiley and Kane (2006), Pavlis et al. (2008), and Gilman et al. (2008a; $2008 \mathrm{~b}$ ) simulated wind conditions to evaluate trunk movement of young trees in response to crown thinning, raising and reduction pruning. Both crown reduction and crown thinning reduced trunk movement (Gilman et al. 2008a; Gilman et al. 2008b) and wind load (Smiley and Kane 2006). Essentially, the more crown mass removed, the lower the trunk movement or wind load. Gilman et al. (2008a) noted the response was a complex one, and the authors cautioned against extrapolating to larger trees.

Moore and Maguire (2005) examined the effects of crownraising on movement of $14 \mathrm{~m}$ to $20 \mathrm{~m}$ Douglas-fir trees. Natural sway frequency increased as pruning level increased, although this was not noticeable until $80 \%$ of the canopy had been removed. Changes in sway frequency were related to how crown mass was distributed. They noted that treating branches as a lumped mass may not be appropriate.

Standards for pruning are found in the U.S. (ANSI 2008), the United Kingdom (British Standards Institute 1989), and Germany (ZTV-Baumpflege 2001). In each case, the standard provides a common vocabulary and procedures for pruning activities. In the U.S., the International Society of Arboriculture (Gilman and Lilly 2002; Kempter 2004) produced a companion volume to the standard, aimed at defining best practice. In a somewhat similar manner, the European Arboricultural Council (2008) recently updated the European Tree Pruning Guide. In Italy, the concept of industry standards remains under discussion (see di Lobis 2003).

\section{RESEARCH TOPICS FOR THE FUTURE}

Arboricultural practice should have a foundation in research. In the area of pruning, a foundation is present to some extent. It seems clear that employing removal and reduction cuts has been documented by experimentation and careful observation. Research by Shigo and more recently by Dujesiefken has supported use of the branch collar, natural target approach to selecting the location of a removal cut. Although less well-defined, the same is true for reduction pruning, primarily through work of Ed Gilman and Jason Grabosky.

In utility arboriculture, reduction cuts take the form of directional pruning-the effort to use a tree's natural growth pattern to aid in maintaining clearance. The literature documents the value of directional pruning and the problems as- 
sociated with topping and traditional roundover trimming. Future research could further validate the few experiments in this area. In addition, research along the line of Millet and Bouchard's (2003) application of architectural analysis to line clearance would enhance the idea of directional growth.

Additional research is needed to support the use of pruning in the area of plant health care. Although effectiveness of sanitation or eradicative pruning has been documented, use of cleaning and thinning to improve overall plant health has not. In a similar manner, an answer to the question, "Does pruning reduce the potential for windthrow, windsnap, or failure during storms?" has not yet been developed. Most recent research has been with relatively small trees rather than mature individuals. A recent article by Kane and Harris (2008) reviews the research on this topic.

Access to non-English language journals and those in fields such as forestry is ever-increasing but is not without its limitations. First, many but not all journals have some online presence. Abstracts can generally be accessed free of charge. Articles, however, must be purchased. A second limitation to a broader application of the world-wide literature is the lack of a common vocabulary. Is early pruning the same as formative pruning? Is forestry's green pruning equivalent to crown raising? Comparison of professional standards will reduce confusion about terms. A third limitation is language, as only few journals provide abstracts in other languages. Fewer still offer table and figure captions in a second language.

Acknowledgments. The authors very much appreciate the comments and suggestions of two anonymous reviewers as well as those of the editor. We acknowledge the encouragement and support of the ISA Science and Research Committee, particularly Greg McPherson and Sharon Lilly. Thanks to the Department of Plant Biology, University of California (Davis) for providing access to the campus library.

\section{LITERATURE CITED}

Harris, R., J. Clark and N. Matheny. 2004. Arboriculture-Integrated management of landscape trees shrubs and vines. 4th edition. Prentice Hall. Upper Saddle River NJ.

Kane, B., and R. Harris. 2008. Does pruning reduce the risk of tree failure? Arborist News 17:46-48.

Shigo, A. 1989. Tree Pruning-A worldwide photo guide. Shigo and Trees Associates. Durham NH.

James R. Clark (corresponding author)

HortScience, Inc.

P.O. Box 754

Pleasanton CA 94566, U.S.

jim@hortscience.com

Nelda Matheny

HortScience, Inc.

P.O. Box 754

Pleasanton CA 94566, U.S
Résumé. Deux cents une publications de recherches, incluant 152 articles de journaux, ont été compilés. Quarante-quatre journaux étaient représentés, et le Journal of Arboriculture, le Arboricultural \& Urban Forestry ainsi que le Arboricultural Journal étaient les plus fréquemment cités. La compartimentation, les blessures, la réaction aux blessures, le développement de la carie et le traitement des blessures étaient les sujets les plus fréquemment traités.

La bibliographie a été montée sur Zotero, une application faisant appel au navigateur Firefox. Les mots-clés ont été identifiés pour chacune des publications. Lorsque l'article ou le résumé était disponible, une annotation a été inscrite. Cet article décrit les sujets majeurs traités qui ont été identifiés dans cette revue et présente une discussion des directions futures en ce qui regarde l'élagage.

Zusammenfassung. 201 Forschungspublikationen, einschließlich 152 Journalartikel wurden zusammengestellt. 44 Journale, einschließlich Journal of Arboriculture, Arboricultural \& Urban Forestry, und Arboricultural Journal als die meist zitierten, wurden präsentiert. Kompartmentalisierung, Verletzung, Wundreaktion, Fäuleentwicklung und Wundbehandlung waren die häufigsten Themen.

Die Bibliographie wurde in Zotero organisiert, eine Applikation von dem Browser Firefox, welcher die Schlüsselworte in jeder Publikation identifiziert. Wo entweder der Artikel oder sein Abstrakt erhältlich war, wurde ein Vermerk gemacht. Diese Studie beschreibt die Hauptthemengebiete, die in der Durchsicht identifiziert wurden und diskutiert die zukünftigen Richtungen für die Baumpflege.

Resumen. Se compilaron 201 publicaciones de investigaciones incluyendo 152 artículos de journal. Cuarenta y cuatro jornals estuvieron representados por el Journal of Arboriculture, Arboricultural \& Urban Forestry, y Arboricultural Journal como los más frecuentemente citados. Compartimentación, herida, respuesta a la herida, desarrollo de la descomposición y tratamiento de heridas fueron los tópicos más frecuentes. La bibliografía estuvo organizada en Zotero, una aplicación que usa el navegador Firefox. Se identificaron palabras claves para cada publicación. Cuando el artículo o su abstract estuvieron disponibles, se creó una anotación. Este trabajo describe los tópicos principales identificados en la revisión y discute las direcciones futuras para la investigación sobre la poda. 


\section{APPENDIX. LITERATURE REVIEW}

American National Standards Institute (ANSI). 2008. ANSI A300 Pruning Standard. American National Standards Institute.

Appel, D. 1994. Identification and control of oak wilt in Texas urban forests. Journal of Arboriculture 20:250-258.

Austad, I., and L. Hauge. 2007. Pollarding in western Norway. In: Proc., European Symp. Tronges (pollards). Vendome Agricultural College. Loir-et-Cher. France.

Bai, S., W. Chaney, and Y. Qi. 2005. Wound closure in trees affected by paclobutrazol. Journal of Arboriculture 31: 273-279.

Baker, F. and D. French. 1985. Economic effectiveness of operational therapeutic pruning for control of Dutch elm disease. Journal of Arboriculture 11:247-249.

Balandier, P. 1997. A method to evaluate needs and efficiency of formative pruning of fast-growing broad-leaved trees and results of an annual pruning. Canadian Journal of Forest Research 27:809-816.

Balder, H., K. Ehlebracht, and E. Mahler. 1997. Straßenbaume. Planen, Pflanzen, Pflegen, am Beispiel Berlins. Berlin, Germany: Patzer-Verlag.

Ball, J. 1992. Response of the bronze birch borer to pruning wounds on paper birch. Journal of Arboriculture 18:294-297.

Barger, J., and W. Cannon. 1987. Response of smaller European bark beetles to pruning wounds on American elm. Journal of Arboriculture 13:102-104

Barry, K., M. Hall, and C. Mohammed. 2005. The effect of time and site on incidence and spread of pruning-related decay in plantation-grown Eucalyptus nitens. Canadian Journal of Forest Research 35:495-502.

Barry, K., R. Pearce, and C. Mohammed. 2000. Properties of reaction zones associated with decay from pruning wounds in plantation-grown Eucalyptus nitens. Forest Pathology 30:233-245.

Barton, I. 1995. Preliminary results from a sailing pruning trial of Cupressus species. New Zealand Tree Grower 16:28-29.

Bauch, J., A. Shigo, and M. Stark. 1980. Wound effects in the xylem of Acer and Betula species. Holzforschung 34: 154-160.

Baum, S., and F. Schwarze. 2002. Large-leaved lime (Tilia platyphyllos) has a low ability to compartmentalize decay fungi via reaction zone formation. New Phytologist 154: 481-490.

Bory, G., G. Hebert, N. Macle, and D. Clair-Maczulajtys. 1996. Physiological consequences of architectural pruning on trees. In: Proc. 2nd European Congress in Arboriculture. Institut pour le Développement Forestier, 111-119. Paris, France.

Brickell, C., and D. Joyce. 1996. The Royal Horticultural Society Pruning and Training. Dorling Kindersley.

Bridgeman, P. 1976. Tree Surgery. London: David \& Charles.

British Standards Institute. 1989. BS 3998 Recommendations for tree work. British Standards Institute. London. United Kingdom.

Broschat, T., and A. Meerow. 2000. Ornamental Palm Horticulture. Gainesville, FL: University of Florida Press.

Brown, G. 2004. The Pruning of Trees, Shrubs and Conifers. 2nd ed. Portland, OR: Timber Press.
Browning, M., and H. Wiant. 1997. The economic impacts of deferring electrical utility tree maintenance. Journal of Arboriculture 23:106-112.

Buhler, O., and P. Kristoffersen. 2009. The Urban Tree Arboretum in Horsholm Denmark: A new tool towards an improved education of arborists and tree managers. Urban Forestry \& Urban Greening 8:55-61.

Butin, H., and A. Shigo. 1981. Radial shakes and "frost cracks" in living oak trees. Research Paper. NE-478. Broomall, PA: U.S. Department of Agriculture, Forest Service, Northeastern Forest Experiment Station.

Camilli, K., D. Appel, and W. Watson. 2007. Studies on pruning cuts and wound dressings for oak wilt control. Arboriculture \& Urban Forestry 33, no. 2:132-130.

Campanella, B., A. Toussaint, and R. Paul. 2009. Mid-term economical consequences of roadside tree topping. Urban Forestry \& Urban Greening 8:49-53.

Chandler, W., and R. Cornell. 1952. Pruning Ornamental Trees, Shrubs and Vines. California Agricultural Extension Service Circular No. 179. Oakland CA

Chandrashekara, U. 2007. Effects of pruning on radial growth and biomass increment of trees growing in homegardens of Kerala, India. Agroforest Systems 69:231-237.

Churack, P., R. Miller, K. Ottman, and C. Koval. 1994. Relationship between street tree diameter growth and projected pruning and waste wood management costs. Journal of Arboriculture 20:231-236.

Clair-Maczulajtys, D., I. Le Disquet, and G. Bory. 1999. Pruning stress: Changes in the tree physiology and their effects on the tree health. In: Proc. International Symposium on Urban Tree Health, 317-324. Acta Horticulturae 496.

Clark, F.B. 1955. Black walnut responds to pruning. Journal of Forestry, 53:362-365.

Close, D., J. Groninger, J. Mangun, and P. Roth. 2001. Homeowners opinions on the practice and effects of topping trees. Journal of Arboriculture 27:160-165.

Coder, K.D., P. Blackburne-Maze, M. Cracknell, and R. Bentley. 1997. Crown pruning effects on roots. In: Proc. 3rd European Arboriculture Congress.

Coombs, D., P. Blackburne-Maze, M. Cracknell, and R. Bentley. 2001. The Complete Book of Pruning. Cassell Paperbacks. England.

Croxton, P., W. Franssen, D. Myhill, and T. Sparks. 2004. The restoration of neglected hedges: A comparison of management treatments. Biological Conservation 117:19-23.

Dahle, G., H. Holt, W. Chaney, T. Whalen, D. Cassens, R. Gazo, and R. McKenzie. 2006a. Branch strength loss implications for silver maple (Acer saccharinum) converted from round-over to V-trim. Arboriculture \& Urban Forestry 32, no. 4:148-154.

Dahle, G., H. Holt, W. Chaney, T. Whalen, J. Grabosky, D. Cassens, R. Gazo, R. McKenzie, and J. Santini. 2006b. Decay patterns in silver maple (Acer saccharinum) trees converted from round-over to V-trims. Arboriculture \& Urban Forestry 32:260-264.

Deflorio, G., K. Barry, C. Johnson, and C. Mohammed. 2007. The influence of wound location on decay extent in plantation- 
grown Eucalyptus globulus and Eucalyptus nitens. Forest Ecology Management 242:353-362.

Doughty, S., C. Hollier, K. Koonce, and P. Orr. 1989. How wound compounds affect pruning wound closure and decay in young swamp red maple trees. HortScience 24:393.

Drenou, C. 1999. La taille des arbres d'ornement (The size of ornamental trees: how to why). Paris, France: Institut pour le developpement forestier .

Drenour, C. 2000. Pruning trees: the problem of forks. Journal of Arboriculture 26:264-269.

Dujesiefken, D. 1991. Der Kronenschnitt in der Baumpflege (Crown cutting in arboriculture). Neue Landschaft 36: 27-31.

Dujesiefken, D. (Ed.) 1995. Wundbehandlung an Bäumen (Wound treatment of trees). Bernhard Thalacker Berlag, Braunschweig.

Dujesiefken, D., C. Drenou, P. Oven, and H. Stobbe. 2005a. Arboricultural practices. In: Urban Forests and Trees, 520. Berlin, Germany: Springer Verlag.

Dujesiefken, D., S. Ebenritter, and W. Liese. 1989. Wundreaktionen im Holzgewebe bei Birke, Buche und Linde (Wound reactions in the wood of birch, beech and basswood). Holz als Roh- und Werkstoff (Germany) 47:495-500.

Dujesiefken, D., T. Kowol, and W. Liese. 1998. Vergleich der Schnittführung bei der Astung von Linde und Roßkastanie (Comparison of the situation of cuts during pruning of linden or horse chestnut). Allgemeine Forstzeitschrift (Germany, F.R.) 43:331-332, 336.

Dujesiefken, D., W. Liese, W. Shortle, and R. Minocha. 2005b. Response of beech and oaks to wounds made at different times of the year. European Journal of Forest Research 124:113-117.

Dujesiefken, D., A. Rhaesa, D. Eckstein, and H. Stobbe. 1999. Tree wound reactions of differently treated boreholes. Journal of Arboriculture 25:113-123.

Dujesiefken, D., and H. Stobbe. 2002. The Hamburg Tree Pruning System - A framework for pruning of individual trees. Urban Forestry \& Urban Greening 1:75-82.

Dujesiefken, D., Horst Stobbe, and D. Eckstein. 1998. Langzeitwirkungen von Astungen im Holz von Linde und Roßkastanie (Long-term effects of pruning on the trunk of lime and horsechestnut). Forstwissenschaftliches Centralblatt - Tharandter Forstliches Jahrbuch 117:305-315.

Duryea, M., G. Blakeslee, W. Hubbard, and R.A. Vasquez. 1996. Wind and trees: A survey of homeowners after Hurricane Andrew. Journal of Arboriculture 22 1:44-49.

Ehsen, H. 1987. Pruning of street trees: Cause, objective and execution. Arboricultural Journal 11:245-263.

Eisner, N.J., E.F. Gilman, and J.C. Grabosky. 2002a. Branch morphology impacts compartmentalization of pruning wounds. Journal of Arboriculture 28:99-105.

Eisner, N.J., E.F. Gilman, J.C. Grabosky, and R.C. Beeson, Jr. 2002b. Branch junction characteristics affect hydraulic segmentation in red maple. Journal of Arboriculture 28:99-105

Ericsson, A., C. Hellqvist, B. Langstrom, S. Larsson, and O. Tenow. 1985. Effects on growth of simulated and induced shoot pruning by Tomicus piniperda as related to carbohydrate and nitrogen dynamics in Scots pine. Journal of Applied Ecology 22:105-124.
European Arboricultural Council. 2008. European Tree Pruning Guide. Bad Honnef/Germany.

Evans, P., and J. Klett. 1984. The effects of dormant pruning treatments on leaf, shoot, and root production from bare-root Malus sargentii. Journal of Arboriculture 10:298-302.

Evans, P., and J. Klett. 1985. The effects of dormant branch thinning on total leaf, shoot, and root production from bareroot Prunus cerasifera 'Newportii'. Journal of Arboriculture 11:149-51.

Fay, N. 2002. Environmental arboriculture, tree ecology and veteran tree management. Arboricultural Journal 26: 213-238.

Fay, N. 2004. Survey methods and development of innovative arboricultural techniques in key UK (United Kingdom) veteran tree sites. In: The trees of history: Protection and exploitation of monumental trees. Proc. International Congress 64-75. Torino, Italy.

Fazio, J., and E. Krumpe. 1999. Underlying beliefs and attitudes about topping trees. Journal of Arboriculture 25:193-199.

Ferrari, F., A. Pestalozza, and R. Casagrandi. 2003. Pruning carefully. Acer 3:41-47.

Ferrari, F. 2004. Summer pruning. Acer 3:53-55.

Ferrini, F. 2004a. Training veteran trees. Part 1. Acer 4:42-46.

Ferrini, F. 2004b. Training veteran trees. Part 2. Acer 5:50-54.

Ferrini, F. 2004c. Management of monumental trees: Review on the effects on physiological balance and tree biomechanics. In: The trees of history: Protection and exploitation of monumental trees. Proc. International Congress 56-63. Torino, Italy: Regione Piemonte Univ. di Torino.

Ferrini, F. 2006a. Potatura degli alberi ornamentali: Effetti sull'equilibrio fisiologico e biomeccanico (Pruning ornamental trees: Effects on physiology and biomechanic equilibrium). Sherwood-Foreste 120:19-22.

Ferrini, F. 2006b. Interventi di potatura e loro effetti sull'equilibrio fisiologico e biomeccanico degli alberti ornamentali. Sherwood 3:19-22.

Ferrini, F. 2006c. Pollarding and its effects on tree physiology: a look to mature and senescent tree management in Italy. In: Colloque européen sur les trognes, 1-8. Vendôme France.

Findlay, C., F. Last, P. Aspinall, C. Ward Thompson, and N. Rudd. 1997. Root and shoot pruning in root-balled Acer platanoides L.: effects of establishment and shoot architecture. Arboricultural Journal 21:215-229.

Forkasiewicz, K. 1998. The design and implementation of a code of practice for low voltage overhead utility pruning of trees. Arboricultural Journal 21:121-128.

Fraedrich, B., and E.T. Smiley. 1996. Maintenance pruning standard: A simplified view. Arborist News 5:49-52

Funk, D. 1979. Stem form response to repeated pruning of young black walnut trees. Canadian Journal of Forest Research 9:114-116.

Galvin, M.F. 2005. Trees and their impact on electric reliability during and following tropical storm Isabel. In: Hurricane Isabel in Perspective. K.G. Sellner (Ed.). Edgewater, MD: Chesapeake Research Consortium, CRC Publication.

Gatti, L. 2003. Precise cutting. Acer 3:42-43.

Gilman, E.F., J. Grabosky, S. Jones, and C. Harchick. 2008a. Effects of pruning dose and type on trunk movement in tropical wind storms. Arboriculture \& Urban Forestry 34:13-19. 
Gilman, E.F. 2002. Illustrated Guide to Pruning. 2nd ed. CENGAGE Delmar Learning, January 15.

Gilman, E.F. 2003. Branch-to-stem diameter ratio affects strength of attachment. Journal of Arboriculture 29:291-294.

Gilman, E.F., and J. Grabosky. 2006. Branch union morphology affects decay following pruning. Arboriculture \& Urban Forestry 32:74-79.

Gilman, E.F., and G. Knox. 2005. Pruning type affects decay and structure of crapemyrtle. Journal of Arboriculture 31:38-47.

Gilman, E.F., and S. Lilly. 2002. Best Management Practices Tree Pruning. International Society of Arboriculture. Champaign, IL.

Gilman, E.F., F. Masters, and J. Grabosky. 2008b. Pruning affects tree movement in hurricane force winds. Arboriculture \& Urban Forestry 34:20-28.

Goodfellow, J., B. Blumreich, and G. Nowacki. 1987. Tree growth response to line clearance pruning. Journal of Arboriculture 13:196-200.

Grabosky, J., and E.F. Gilman. 2007. Response of two oak species to reduction pruning cuts. Arboriculture \& Urban Forestry 33:360-366.

Grabosky, J., E.F. Gilman, and C. Harchick. 2007. Use of branch cross-sectional area for predicting pruning dose in young field-grown Quercus virginiana 'Cathedral' in Florida, US. Urban Forestry \& Urban Greening 6:159-167.

Green, D., W. Shortle, and A. Shigo. 1981. Compartmentalization of discolored and decayed wood in red maple branch stubs. Forest Science 27:519-522.

Gregory, G., and J. Allison. 1979. The comparative effectiveness of pruning versus pruning plus injection of trunk and/or limb for therapy for Dutch elm disease in American elms. Journal of Arboriculture 5:1-4.

Guggenmoos, S. 2007. Increased risk of electrical service interruption associated with tree branches overhanging conductors. Utility Arborist Assoc. Quart. 15:8-14.

Guimond, C., G. Lang, and P. Andrews. 1998. Timing and severity of summer pruning affects flower initiation and shoot regrowth in sweet cherry. HortScience 33:647-649.

Halliwell, B., J. Turpin, and J. Wright. 1979. The Complete Handbook of Pruning. 2nd ed. London: Ward Lock.

Hanley, D., C. Oliver, D.A. Maguire, D. Briggs, and R. Fight (Eds.). 1995. Forest pruning and wood quality of western North American conifers. University of Washington Institute of Forest Research \#77. Seattle WA.

Harris, R. 1975. Pruning fundamentals. Journal of Arboriculture 1:221-226.

Harris, R. 1994. Clarifying certain pruning terminology: thinning, heading, pollarding. Journal of Arboriculture 20:50-54.

Hensley, D. 1979. Pruning: Why, when and how. Journal of Arboriculture 5:239-240.

Herring, H.G., V.J. Rudolph, and W.A. Lemmien. 1958. Wound area as influenced by closeness of pruning. Journal of Forestry 56:219-220.

Himelick, E., and D. Ceplecha. 1976. Dutch elm disease eradication by pruning. Journal of Arboriculture 2:81-84.

Holewinski, D., J. Orr, and J. Gillon. 1983. Development of improved tree trimming equipment and technique. Journal of Arboriculture 9:137-40.

Hoster, R. 1993. Baumpflege und Baumschutz (Tree Care and Tree Protection). Stuttgart, Germany: Verlag Eugen Ulmer.
Hudler, G., and S. Jensen-Tracy. 1999. Lac Balsam ${ }^{\circledR}$ as a treatment to hasten wound closure and minimize discoloration and decay. Journal of Arboriculture 28:264-269.

Johnson, D. 2007. Pruning. In Urban and Community Forestry in the Northeast. New York, NY: Springer.

Johnstone, R. 1983. Management techniques for utility tree maintenance. Journal of Arboriculture 9:17-20.

Johnstone, R. 1988. Economics of utility lateral trimming. Journal of Arboriculture 14:74-77.

Kane, B. 2007. Branch strength of Bradford pear (Pyrus calleryana var. Bradford). Arboriculture \& Urban Forestry 33:283-291.

Kane, B. 2008. Tree failure following a windstorm in Brewster Massachusetts USA. Urban Forestry \& Urban Greening 7:15-23.

Kane, B., and R. Farrell. 2008. Failure mode and prediction of the strength of branch attachments. Arboriculture \& Urban Forestry 34:308-316.

Kappel, F., M. Bouthillier, and R. Brownlee. 1997. Summer pruning young 'Sweetheart' sweet cherry trees affects yield and tree size. HortScience 32:1034-1036.

Karlovich, D., J. Groninger, and D. Close. 2000. Tree condition associated with topping in southern Illinois communities. Journal of Arboriculture 26:87-91.

Kempter, G. 2004. Best Management Practices Utility Pruning of Trees. International Society of Arboriculture. Champaign, IL.

Kerr, G., and R. Harmer. 2001. Production of epicormic shoots on oak (Quercus robur): effects of frequency and time of pruning. Forestry 74:467-477.

Kerr, G., and G. Morgan. 2006. Does formative pruning improve the form of broadleaved trees? Canadian Journal of Forest Research 36:132-141.

Kimball, B., D. Nolte, D. Griffin, S. Dutton, and S. Ferguson. 1998. Impacts of live canopy pruning on the chemical constituents of Douglas-fir vascular tissues: Implications for black bear tree selection. Forest Ecology Management 109:51-56.

Kramer, E., and M. Borkowski. 2004. Wood grain patterns at branch junctions: modeling and implications. TreesStructure \& Function 18:493-500.

Kuhns, M., and D. Reiter. 2007. Knowledge and attitudes about utility pruning and how education can help. Arboriculture \& Urban Forestry 33:264-274.

Langstrom, B., and C. Hellqvist. 1991. Effects of different pruning regimes on growth and sapwood area of Scots pine. Forest Ecology Management 44 2-4:239-254.

Langstrom, B., H. Solheim, C. Hellqvist, and R. Gref. 1993. Effects of pruning young Scots pines on host vigour and susceptibility to Leptographium wingfieldii and Ophiostoma minus, two blue-stain fungi associated with Tomicus piniperda. European Journal of Forest Pathology 23:400-415.

Ledin, R. 1961. Pruning Palms. American Horticulture Magazine 40:142-143.

Leiser, A., R. Harris, P.L. Neel, D. Long, N. Stice, and R. Maire. 1972. Staking and pruning influence trunk development of young trees. Journal of American Society Horticultural Science 97:498-503. 
Lev-Yadun, S., and R. Aloni. 1990. Vascular differentiation in branch junctions of trees: circular patterns and functional significance. Trees- Structure \& Function 4:49-54.

Li, M., P. Uehre, and J. Matschke. 2001. Diameter growth and stem form development of young trees, depending on pruning activity. Schweizerische Zeitschrift fur Forstwese 152:389-393.

Liese, W., and D. Dujesiefken. 1996. Wound reactions in trees. In: Forest trees and palms. Diseases and control. S.P. Raychaudhuri (Ed.) and K. Maramorosch, 21-35. New Delhi, Calcutta: Oxford and IBH Publishing Co.

Liese, W., D. Dujesiefken, and J. Bremer. 1988. Wundreaktionen bei Linde nach Astung in der Baumpflege (Wound reactions of lime trees following pruning during tree care). Forstwissenschaftliches Centralblatt (Germany) 107:184-196.

Lippi, P. 1994a. Tree pruning: aims and types. Part 1. Acer 2:18-19.

Lippi, P. 1994b. Tree pruning: aims and types. Part 2. Acer 3:19-21.

di Lobis, V., and M. Tomasi. 2003. La classificazione degli interventi di manutenzione degli alberi (System of classification for tree care). Sherwood-Foreste 94:39-45.

Lonsdale, D. 1993. A comparison of "target"pruning, versus flush cuts and stub pruning. AAIS Arboriculture Research Note 116/93/PATH.

Lonsdale, D. 2008. BS 3998 Recommendations for tree work: likely implications of the next edition. Arboricultural Journal 31:19-31.

Luley, C., S. Sisinni, and A. Pleninger. 2002. The effect of pruning on service requests, branch failures, and priority maintenance in the City of Rochester New York U.S. Journal of Arboriculture 28:137-143.

Malins, J. 1997. The Pruner's Handbook. Practical pruning advice for healthy, beautiful plants. 2nd ed. Devon, United Kingdom: David \& Charles.

Margolis, H., R. Gagnon, D. Pothier, and M. Pineau. 1988. The adjustment of growth, sapwood area, heartwood area, and sapwood saturated permeability of balsam fir after different intensities of pruning. Canadian Journal of Forest Research 18:723-727.

Mascelli, M., F. Menchi, and A. Gabellini. 2008. Alberature mature in ambiente urbano: Un case nella citta di Prato (Urban plant stand: A study in Prato Italy). Sherwood-Foreste 142:37-41.

Mayer-Wegelin, H. 1936. Astung. Hanover, Germany: M. \& H. Schaper.

Mayer-Wegelin, H. 1952. Das Aufasten der Waldbaume (Pruning forest trees). 3rd ed. Hannover, Germany: Schaper-Verlag.

McGillivary, L., S. Wiest, and D. Hensley. 1996. A survey of line clearance operations in Kansas US. Journal of Arboriculture 22:281-282.

McQuilkin, W.E. 1950. Effects of some growth regulators and dressings on the healing of tree wounds. Journal of Forestry 48:423-28.

Mercer, P., S. Kirk, P. Gendle, and D.R. Clifford. 1983. Chemical treatments for control of decay in pruning wounds. Annals Applied Biology 102:435-453.

Mercer, P.C., and S. Kirk. 1984a. Biological treatments for the control of decay in tree wounds: Laboratory tests. Annals Applied Biology 104:211-219.
Mercer, P.C., and S. Kirk. 1984b. Biological treatments for the control of decay in tree wounds: Field tests. Annals Applied Biology 104:221-229.

Miller, R., and W. Sylvester. 1981. An economic evaluation of the pruning cycle. Journal of Arboriculture 7:109-112.

Miller, V. 1959. Crotch influence on strength and breaking point of apple tree branches. Proc. American Society Horticultural Science 73:27-32.

Millet, J., and A. Bouchard. 2003. Architecture of silver maple and its response to pruning near the power distribution network. Canadian Journal of Forest Research 33:726-739.

Monnier, R. 2003. A new pruning method for living branches with a thin collar. Forst und Holz 58:661-664.

de Montigny, L., and S. Stearns-Smith. 2001. Pruning density and severity in coastal western hemlock: 4-year results. Ministry of Forests Research Program. British Columbia. Canada.

Moore, J., and D. Maquire. 2005. Natural sway frequencies and damping ratios of trees: influence of crown structure. Trees - Structure and Function 19:363-373.

Moorman, G., and R. Lease. 1999. Effects of pruning in the management of dogwood and pine branch dieback in the landscape. Journal of Arboriculture 25:274-277.

Neely, D. 1970. Healing of wounds on trees. Journal of American Society Horticultural Science 95:536-40.

Neely, D. 1979. Tree wounds and wound closure. Journal of Arboriculture 5:135-40.

Neely, D. 1988a. Closure of branch pruning wounds with conventional and 'Shigo' cuts. Journal of Arboriculture 14: 261-64.

Neely, D. 1988b. Wound closure rates on trees. Journal of Arboriculture 14:250-54.

Neely, D. 1988c. Tree wound closure. Journal of Arboriculture $14: 148-52$.

Neilsen, W., and E. Pinkard. 2003. Effects of green pruning on growth of Pinus radiata. Canadian Journal of Forest Research 33:2067-2073.

Nowak, D. 1990. Street tree pruning and removal needs. Journal of Arboriculture 16:309-315.

O'Hara, K. 1991. A biological justification for pruning in coastal Douglas-fir stands. Western Journal of Applied Forestry 6:59-63.

O'Hara, K. 2007. Pruning wounds and occlusion: A long-standing conundrum in forestry. Journal of Forestry 105:131-138.

Oleksak, B., M. Kmetz-Gonzales, and D. Struve. 1997. Terminal bud cluster pruning promotes apical control in transplanted shade tree whips. Journal of Arboriculture 23:147-154.

Opgenorth, D., L. Butler, and M. Arciero. 1983. Transmission of Ceratocystis ulmi on pruning saws. Journal of Arboriculture 9:196-197.

Pavlis, M., B. Kane, J.R. Harris, and J.R. Seiler. 2008. The effect of pruning on drag-induced bending moment of shade trees. Arboriculture \& Urban Forestry 34:207-215.

Pearce, R. 2000. Decay development and its restriction in trees. Journal of Arboriculture 26:1-11.

Perry, E., and G. Hickman. 1987. Wound closure in eucalyptus. Journal of Arboriculture 13:201-202.

Peterson, J., and D. Helmer. 1992. A wound treatment system to suppress cankers and wood rots in trees. Journal of Arboriculture 18:155-160. 
Pfisterer, J. 1999. Geholzschnitt nach den Gesetzen der Natur (Tree pruning according to the laws of nature). Stuttgart, Germany: Verlag Eugen Ulmer.

Pietilä, J. 1989. Factors affecting the healing-over of pruned Scots pine knots. Silva Fennica 23:125-158.

Pinkard, E.A. 2002. Effects of pattern and severity of pruning on growth and branch development of pre-canopy closure Eucalyptus nitens. Forest Ecology Management 157: 217-230.

Pinkard, E.A., M. Battaglia, C.L. Beadle, and P.J. Sands. 1999. Modeling the effect of physiological responses to green pruning on net biomass production of Eucalyptus nitens. Tree Physiology 19:1-12.

Pinkard, E.A., and C.L. Beadle. 1998. Effects of green pruning on growth and stem shape of Eucalyptus nitens. New Forests 15:107-126.

Reich, P., M. Walters, S. Krause, D. Venderklein, K. Raffs, and T. Tabone. 1993. Growth, nutrition and gas exchange of Pinus resinosa following artificial defoliation. Trees-Structure and Function 7:67-77.

Schatz, U., K. Kannisto, and M. Rantatalo. 2008. Influence of saw and secateur pruing on stem discolouration, wound cicatrisation and diameter growth of Betula pendula. Silva Fennica 42:295-305.

Schnelle, M., and J. Klett. 1992. Effects of pruning and bark ringing on total nonstructural carbohydrates in crabapple. Journal of Arboriculture 18:192-196.

Schubert, M., S. Fink, and F. Schwarze. 2008a. In vitro screening of an antagonistic Trichoderma strain against wood decay fungi. Arboricultural Journal 31:227-248.

Schubert, M., S. Fink, and F. Schwarze. 2008b. Field experiments to evaluate the application of Trichoderma strain (T-15603.1) for biological control of wood decay fungi. Arboricultural Journal 31:249-268.

Schwarze, F. 2001. Development and prognosis of decay in the sapwood of living trees. Arboricultural Journal 25:321-337.

Schwarze, F., J. Gruner, J. Schubert, and S. Fink. 2007. Defence reactions and fungal colonisation in Fraxinus excelsior and Tilia platyphyllos after stem wounding. Arboricultural Journal 30:61-82.

Schwarze, F., and C. Heuser. 2006. Stem wounds - potential entry courts for wood decay fungi? Arboricultural Journal 29:101-119.

Shigo, A. 1981. To Paint or Not to Paint. In: Handbook of Pruning, 20-23. Plants \& Gardens. 37(2): Brooklyn Botanic Garden.

Shigo, A. 1983. Targets for proper tree care. Journal of Arboriculture 9:285-94.

Shigo, A. 1984. Compartmentalization: a conceptual framework for understanding how trees grow and defend themselves. Annual Review Phytopathology 22:189-214.

Shigo, A. 1985. How tree branches are attached to trunks. Canadian Journal of Botany 63:1391-1401.

Shigo, A. 1989. Tree Pruning: A Worldwide Photo Guide. Shigo and Trees, Associates. Durham NH.

Shigo, A. 1990. Pruning Trees near Electric Utility Lines. Durham, NH: Shigo and Trees, Associates. Durham NH.

Shigo, A., and E. Larson. 1969. Photo guide to the patterns of discoloration and decay in living northern hardwood trees. Research Paper. USDA Forest Service.
Shigo, A., and H. Marx. 1977. Compartmentalization of decay in trees. Agricultural Information Bulletin No. 405. USDA Forest Service.

Shigo, A., E. McGinnes, D. Funk, and N. Rogers. 1979. Internal defects associated with pruned and non-pruned branch stubs in black walnut. Research Paper. No 440. Broomall, PA: U.S. Department of Agriculture, Forest Service, Northeastern Forest Experiment Station.

Shigo, A., and C. Wilson. 1977. Wound dressings on red maple and American elm: Effectiveness after five years. Journal of Arboriculture 3:81-87.

Shortle, W. 1979. Mechanisms of compartmentalization of decay in living trees. Phytopathology 69:1147-1151.

Slabaugh, P. 1957. Effects of live crown removal on the growth of red pine. Journal of Forestry 55:904-906.

Smiley, E.T. 2003. Does included bark reduce the strength of codominant stems? Journal of Arboriculture 29:104-106.

Smiley, E.T., C. Greco, and J. Williams. 2000. Brace rods for codominant stems: installation location and breaking strength. Journal of Arboriculture 26:170-176.

Smiley, E.T., and B. Kane. 2006. The effects of pruning type on wind loading of Acer rubrum. Arboriculture \& Urban Forestry $32: 33-40$.

Smith, D., B. Larson, M. Kelty, and P. Ashton. 1996. The Practice of Silviculture: Applied Forest Ecology 9th ed. New York: Wiley.

Smith, K. 2006. Compartmentalization today. Arboricultural Journal 29:173-184.

Stefulesco, C. 1995. Traditional pruning in France. In: 2nd European Arboricultural Congress. Versailles France.

Stobbe, H., U. Schmitt, D. Eckstein, and D. Dujesiefken. 2002a. Behandlungsmöglichkeiten von frischen Anfahrschäden an Alleebäumen (Possible treatment of fresh wounds on street trees). In: Jahrbuch der Baumpflege (Yearbook of tree care). D. Dujesiefken (Ed.) and P. Kockerbeck, 43-55. Thalacker Medien, Braunschwieg.

Stobbe, H., U. Schmitt, D. Eckstein, and D. Dujesiefken. 2002b. Developmental stages of fine structure of surface callus formed after debarking of living lime trees. Annals Botany 89:773-782.

Svihra, P. 1994. Principles of eradicative pruning. Journal of Arboriculture 20:262-71.

Toussaint, A., V. Kervyn de Meerendre, B. Delcroix, and J. Baudoin. 2002. Analysis of physiological and economical impacts of the roadside trees pruning. Biotechnology, Agronomy, Society, and Environment 6:99-107.

von Aufsess, H. 1975. The formation of a protective zone at the base of branches of broad-leaved and coniferous trees and its effectiveness in preventing fungi from penetrating into the heartwood of living trees. Forstwissenschaftliches Centralblatt (German Journal of Forest Science) 94:140-152.

von Aufess, H. 1984. Some examples of wood discolourations related to mechanisms for potential protection of living trees against fungal attack. Intern. Assoc. Wood Anatomy Bulletin 5:133-138.

Wang, S.-Y., C.-M. Chiu, and C.-J. Lin. 2003. Application of the drilling resistance method for annual ring characteristics: evaluation of Taiwania (Taiwania cryptomerioides) trees grown with different thinning and pruning treatments. Journal of Wood Science 49:116-124. 
Wardlaw, T., and W. Neilsen. 1999. Decay and other defects associated with pruned branches of Eucalyptus nitens. Tasforests 11:49-57.

Watson, G. 1998. Tree growth after trenching and compensatory crown pruning. Journal of Arboriculture 24:47-53.

Wilson, B. 2000. Apical control of branch growth and angle in woody plants. American Journal of Botany 87:601-607.

Wiseman, D., P. Smethurst, L. Pinkard, T. Wardlaw, C.L. Beadle, M. Hall, C. Baillie, and C. Mohammed. 2006. Pruning and fertiliser effects on branch size and decay in two Eucalyptus nitens plantations. Forest Ecology Management 225:123-133.

Yamamoto, S. 1985. Programmed tree pruning and public liability. Journal of Arboriculture 11:15-17.

ZTV-Baumpflege. 2001. Additional technical agreements and guidelines for arboriculture. 4th edition. Forschungsgesellschaft Landschaftsentwicklung - Landschaftsbau.e (FLL). 